\title{
(5)ＩI/TV-DR における被曝線量と画像特性の関係
} \section{The relationship of the imaging properties in II/TV based DR system to} the incident exposures

\section{(財癌研究会附属病院 小倉敏裕}

数年前より登場したII/TV方式1024X1024マトリクスディジタル・ラジオグラフィ(以下DRとする)や、従来 からある100mmロールフィルムを用いたシステムでは、I.I.のX線検出効率が高く被嚗低減が可能である反面、 空間分解能がscreen/film system（以下S/Fとする）に劣る。しかし、最近登場したII/TV方式2048X2048マトリ クスDRは、大口径の二次蛍光面を有するIIや、新たに開発されたTVカメラ、光学系の採用により空閒分解 能がCR(HR)並にまで改善された。

ルーチンの消化管撮影での被曝線量は、間接撮影並で、S/F[HR6/HRS]と比較した場合、12インチモード

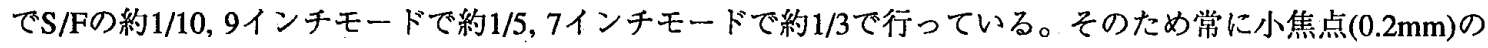
使用が可能で、焦点寸法に起因する幾何学的不鋭が小さくなり、空間分解能の高い画像が得られる。

解像特性は、同一インチモードにおいてもアイリス径とピクセル值がそれぞれ大きくなると低下すること がわかった。このことは、入射線量の増減により解像特性が変化することを意味する。

1.アイリス径を一定に保ち、入射線量を增すとピクセル值が上昇し解像特性が低下する。

2.ピクセル值を一定に保つためにアイリス径を広くし、入射線量を減ずると解像特性が低下する。 すなわち、高い解像特性の画像を得るためには、アイリス径を絞り、低いピクセル值となるような線量で撮 影する。逆に高い解像特性を必要としない場合、アイリス径を広くすることによって被曝低隇が可能である。

ノイズに関しては、当然、線量の低減によって量子モトルが増加する。そして、コントラスト分解能も 覀くなる。しかし、II/TVシステムに特有な高いDQEにより、DR7インチモードではS/F[HR6/HRS]の40\%の 線量でS/Fと同等の低コントラスト被写体検出能を有している。また、ノイズ特性は、解像特性と密接な関 係があるため、アイリス径や、ピクセル值、入射線量によっても大きく異なる。

このように、II/TV-DRの場合、入射線量と解像特性とノイズ特性の間には、複雑な関係があり、これらの 特性を熟知したうえで撮影目的にあったDR装置のパラメータの設定、線量を決定する必要がある。 